\title{
A Criticism of the Sale of Business Doctrine
}

Federal appellate courts are in disagreement ${ }^{1}$ over the validity of the "sale of business" doctrine. This doctrine holds that when a business changes hands through the sale of $100 \%$ of its stock-or, in some instances, a controlling block ${ }^{2}$ - such stock is not a security for purposes of the federal securities laws. ${ }^{3}$ While the federal securities laws exphicitly define a security to include stock, ${ }^{4}$ the sale of business doctrine states that in this particular context stock is not a security. The doctrine thus could greatly circumscribe the scope of the federal securities laws.

The courts that have adopted the sale of busmess doctrine hold that a security exists ouly if there is an imvestment in a common enterprise with the expectation of profits to be derived from the entrepreneurial or managerial efforts of others. ${ }^{5}$ This test is based on the United States Supreme Court decision in SEC v. W.J. Howey Co. ${ }^{6}$ These courts contend that the test allows them to examime the substance of the transaction rather than its form. ${ }^{7}$ They hold that since the buyer of a business expects to earn profits through his own efforts, rather than by those of others, the Howey test ${ }^{8}$ is not satisfied when a busmess is sold. Such a sale is regarded as the commercial sale of a

1. Compare Sutter v. Groen, 687 F.2d 197 (7th Cir. 1982) (upholding doctrine), with Golden v. Garafalo, 678 F.2d 1139 (2d Cir. 1982) (rejecting doctrine).

2. See, e.g., Sutter, 687 F.2d 197.

3. Securities Act of 1933, Pub. L. No. 73-22, 48 Stat. 74 (1933) (codified as amended at 15 U.S.C. $\S \S 77 a-77 a a$ (1976)); Securities Exchange Act of 1934, Pub. L. No. 73-291, 48 Stat. 881 (1933) (codified as amended at 15 U.S.C. $\$ \S 78 \mathrm{a}-78 \mathrm{kk}(1976))$.

4. See infra notes 19-23 and accompanying text.

5. See, e.g., Frederiksen v. Poloway, 637 F.2d 1147, 1152 (7th Cir.), cert. denied, 451 U.S. 1017 (1981); Seagrave Corp. v. Vista Resources, Inc., 534 F. Supp. 378, 381 (S.D.N.Y. 1982).

The latter elemeut has been interpreted as precluding control over manageincnt, as well as active management itself. Frederiksen, 637 F.2d at 1152-53.

6. 328 U.S. 293 (1946).

The courts have applied a inodified form of the Howey test. The Howey Court required that the investor be led to expect profits solely from the efforts of a third party. The sale of business cases have dispensed with the "sole efforts" requirenent. See, e.g. , Frederiksen, 637 F.2d at 115254.

7. See, e.g., King v. Winkler, 673 F.2d 342, 344 (11th Cir. 1982); Frederiksen, 637 F.2d at 1150.

8. This Comment will refer to the Howey test to inean the test applied by the sale of business cases following United Hous. Found., Inc. v. Forman, 421 U.S. 837 (1975), discussed at infra notes 44-52. See infra text accompanying note 62 . 
business, rather than a traditional investment deserving the protection of the securities laws.

Courts that reject the sale of business doctrine hold that the Howey test should not be applied to stock. ${ }^{9}$ They contend that because stock is specifically listed in the statutory definition of a security, it necessarily falls within the coverage of the securities laws. ${ }^{10}$ These courts also stress the conceptual inconsistencies and administrative difficulties of the doctrine. ${ }^{11}$ For example, in a single transaction involving a single type of stock, the doctrine may afford the protection of the securities laws to soine parties but not to others. ${ }^{12}$

Application of the doctrine has significant consequences to buyers and sellers of businesses. It provides both substantive and procedural advantages to defendants in securities fraud cases arising out of the transaction. If the doctrine is applied, plaintiffs cannot bring fraud actions in federal court under rule $10 \mathrm{~b}-5,13$ and instead must sue under state law. Under rule 10b-5, reliance is presumed if an omission is naterial. ${ }^{14}$ A plaintiff asserting a fraud claim in state court, on the other hand, must prove that he relied on the defendant's conduct. ${ }^{15}$ Procedurally, the doctrine may bar plaimtiffs' access to a federal forum by defeating federal subject matter jurisdiction. ${ }^{16}$ It also precludes plaintiffs from taking advantage of the broad venue provisions and nationwide service of process rules authorized by the Securities Exchange Act of 1934. ${ }^{17}$ The sale of business doctrine is also of importance to finders, business brokers, and others who would otherwise be required to register as brokers or dealers. ${ }^{18}$

This Comment argues that the the sale of business doctrine should be rejected. Neither the legislative history nor Supreme Court prece-

9. See, e.g., Coffin v. Polishing Machs., Inc., 596 F.2d 1202, 1204 (4th Cir.), cert. denied, 444 U.S. 868 (1979); Titsch Printing, Inc. v. Hastings, 456 F. Supp. 445, 449 (D.Colo. 1978); Bronstein v. Bronstein, 407 F. Supp. $925,927-28$ (E.D. Pa. 1976).

10. See, e.g., Coffin, 596 F.2d at 1204.

11. See, e.g., Golden, 678 F.2d at 1145-46.

12. See infra Section B of Part II.

13. Rule 10b-5, 17 C.F.R. \$ $240.10 b-5$ (1982).

14. Affiliated Ute Citizens v. United States, 406 U.S. 128, 152-54 (1972). There are also other substantive advantages in bringing an action under the federal law. See, e.g., Nelson v. Serwold, 576 F.2d 1332 (9th Cir.) (recklessness may support hability under rule 10b-5), cert. denied, 439 U.S. 970 (1978); List v. Fashion Park, lnc., 340 F.2d 457 (2d Cir. 1965) (nondisclosure of material information is actionable); 3 A. BRomberG, SECURITIEs FraUd \& CoMmodities FraUd 193-223 (1981).

15. Kahn v. Lischner, 128 Cal. App. 2d 480, 489, 275 P.2d 539, 544 (1954); W. Prosser, HANDBOOK OF THE LAW OF TORTS \& 108 (4th ed. 1971).

16. 15 U.S.C. $\$ 78$ aa (1976).

17. Id.

18. See Seldin, When Stock is Not a Security: The "Sale of Business" Doctrine Under the Federal Securities Laws, 37 Bus. LAw. 637, 640 n.8 (1982). 
dent justifies a departure from the statutory definition. Moreover, application of the doctrine would lead to administrative problems and anomalous results. Part I of this Comment analyzes the legal background and the development of the sale of busmess doctrine. Part II analyzes the cases that have confronted the issue and concludes that the cases that have rejected the doctrine present the better-reasoned view.

LEGAL BACKGROUND

\section{A. Statutory Definitions of "Security"}

The Securities Act of 1933 and the Securities Exchange Act of 1934 both contain specific definitions of a security. ${ }^{19}$ These definitions consist of a list of specific instruments, including stock, that are deemed to constitute securities. The specific mstruments are then followed by more general catchall phrases, such as "investment contract" and "any imstrument commonly known as a 'security." "20 Simce the statutes do not provide a specific definition of these more general terns, the courts lave had to provide common law definitions. ${ }^{21}$

The definitions in the Securities Acts apply "unless the context otherwise requires."22 This clause, whicl precedes both definitional

19. Section 2(1) of the Securities Act of 1933,15 U.S.C. $\& 77 b(1)$ (1976), defines a security as: [u]nless the context otherwise requires . . . any note, stock, treasury stock, bond, debenture, evidence of indebtedness, certificate of interest or participation in any profit-sharing agreement, collateral-trust certificate, preorganization certificate or subscription, transferable share, investınent contract, voting-trust certificate, certificate of deposit for a security, fractional undivided interest in oil, gas, or other inineral rights, or, in general, any interest or instrument commonly known as a "security", or any certificate of interest or participation in, temporary or interim certificate for, receipt for, guarantee of, or warrant or right to subscribe to or purchase, any of the foregoing.

Section 3(a)(10) of the Securities Exchange Act of 1934, 15 U.S.C. $\S 78 \mathrm{c}(\mathrm{a})(10)$ (1976), provides an almost identical definition:

(a) When used in this chapter, unless the context otherwise requires-

…

(10) The term "security" means any note, stock, treasury stock, bond, debenture, certificate of interest or participation in any profit-sharing agreement or in any oil, gas, or other mimeral royalty or lease, any collateral-trust certificate, preorganization certificate or subscription, transferable share, investunent contract, voting-trust certificate, certificate of deposit, for a security, or in general, any instrument commonly known as a "security"; or any certificate of interest or participation in, temporary or interim certificate for, receipt for, or warrant or right to subscribe to or purchasc, any of the foregoing; but shall not include currency or any note, draft, bill of exchange, or banker's acceptance which has a maturity at the time of issuance of not exceeding nine months, exclusive of days of grace, or any renewal thereof the maturity of which is likewise limited.

20. See supra note 19.

21. For example, while there is no statutory definition of imvestment contract, that term had been used consistently in state blue sky laws, and its ineaning had been crystallized by judicial interpretation. Howey, 328 U.S. at 298; SEC v. C.M. Joiner Leasing Corp., 320 U.S. 344 (1943).

22. See supra note 19. There is some controversy, though, as to whether "context" refers only to the appearance of the defined term in the statute itself, or to the factual context as well. See Seldin, supra note 18, at 669 . However, even to the extent the prefatory language inay be 
sections, ${ }^{23}$ has played an important role in the development of the sale of business doctrine. While it creates a presumption that stock is within the statutory definitions of "security," it allows courts to conclude that an instrument within the specific terms of the definition is nonetheless not a security.

"Context" may be interpreted in two ways, however. First, it may refer to the attributes of the specific instrument involved. If an instrument's status as a security is challenged because it lacks the characteristics of stock, for example, a court would decide whether the instrument possesses dividend rights, voting power, or other attributes traditionally associated with stock. If the stock substantially lacks such attributes, it will not be considered a security. ${ }^{24}$ The alternative regulatory structures surrounding a particular type of instrument may also be an attribute for the purposes of deciding the context issue..$^{25}$

Context may also refer to the nature of the transaction in which the instrument is transferred, as opposed to the instrument itself. The sale of business cases have used a transaction analysis to determine whether the context requires the exclusion of an instrument from the definition of a security. ${ }^{26}$ The reach of the transactional interpretation depends on the specific circumstances and parties involved in a particular transaction. Using the transaction analysis, the sale of business cases have found that the sale of $100 \%$ of a busmess' stock is a transaction that should escape the scope of the securities laws. ${ }^{27}$

\section{B. Legislative Intent}

The courts that have adopted the sale of business doctrine rely heavily on legislative intent in defining the scope of the word "security." 28 They argue that the Acts were created to protect the investor

deemed to refer to the factual context, the question remains whether the sale of busimess transaction is a context which would otherwise require avoidance of the literal terms of the definition.

23. See supra note 19.

24. See, e.g., Coffin, 596 F.2d at 1204; Bronstein, 407 F. Supp. at 928.

25. In Marine Bank v. Weaver, 455 U.S. 551 (1982), the Supreme Court held that an instrument which was adequately protected by the banking regulations was not a security although arguably within the teruns of the definition.

26. E.g., Frederiksen, 637 F.2d at 1152 .

27. A number of lower courts have employed a commercial/investinent dichotomy to determine whether a note is a security. See, e.g., Exchange Nat'l Bank v. Touche, Ross \& Co., 544 F.2d 1126 (2d Cir. 1976); McClure v. First Nat'1 Bank, 497 F.2d 490 (5th Cir. 1974), cert. denied, 420 U.S. 930 (1975). However, as a policy inatter, situations involving notes may more strongly require avoidance of the specific terms of the definition, due to the wide variety of consumer transactions in which notes are given. The Bronstein court observed that the securities laws are not designed to protect persons engaged in ordinary or cominercial loan transactions and that their application would unnecessarily burden commercial paper markets. 407 F. Supp. at 930 . Moreover, the Supreme Court has not yet decided the issue.

28. Sutter, 687 F.2d at 201; Frederiksen, 637 F.2d at 1150-52. 
rather than the entrepreneur. They then categorize the buyer of $100 \%$ of a business' stock as an entrepreneur, and hold that a transaction involving the sale of a business requires the exclusion of stock in order to effectuate the Acts' underlying purposes.

Courts adopting the doctrine point to the fact that Congress' primary motivation was the protection of investors and the regulation of the securities exchanges. The Securities Exchange Act of 1934 grew out of a Senate investigation into the stock market after the 1929 crash wiped out many investors. ${ }^{29}$ President Roosevelt, in proposing the adoption of a national securities law, ${ }^{30}$ and congressional reports discussing the proposed legislation ${ }^{31}$ stressed the importance of protecting imvestors. The methods chosen to regulate the securities markets-full disclosure and antifraud laws-also suggest a strong concern for imvestors. ${ }^{32}$

Courts that have rejected the sale of business doctrine note that the drafters desired a broad definition of the word "security." Congress defined the term "security" in an expansive maimer. ${ }^{33}$ The House Report accompanying the legislation stated that the definition was imtended to cover "the many types of instruments that in our commercial world fall within the ordinary concept of a security." 34 Moreover, courts have viewed the Acts as remedial measures requiring broad and flexible construction, and "capable of adaptation to meet the countless and variable scheines devised." 35

29. See Loomis, The Securities Exchange Act of 1934 and the Investment Advisors Act of 1940, 28 GEO. WASH. L. Rev. 214, 216-17 (1959).

30. The President's message prompting the Securities Act of 1933 spoke in terms of "the supervision of traffic in imvestment securities." SeNATE COMM. ON BANkING AND CURRENCY, Regulation of Securities, S. Rep. No. 47, 73d Cong., 1st Sess. 6 (1933) thereinafter cited as Senate Report No. 47]; House Comm. on Interstate and Foreign Commerce, Federal

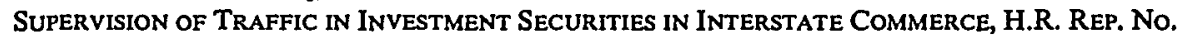
85, 73d Cong., lst Sess. 1 (1933) [hereinafter cited as HousE RePoRT]. His message proinpting the legislation that became the Securities Exchange Act of 1934 spoke of "property dealt with on exchanges" and "regulating the investment business." SENATE COMM. ON BANKING AND CURRenCy, Federal Securities Exchange Act of 1934, S. Rep. No. 792, 73d Cong., 2d Sess. 1 (1934) [heremafter cited as SENATE RePORT No. 792]; House COMM. ON INTERSTATE AND Foreign Commerce, Securities Exchange Bill of 1934, H.R. Rep. No. 1383, 73d Cong., 2d Sess. 1 (1934).

31. See, e.g., SenATE RePORT No. 47, supra note 30, at 1; House RePort, supra note 30, at 1; Comment, Commercial Notes and Definitions of 'Security' Under Securittes Exchange Act of 1934: A Note is a Note is a Note?, 52 NEB. L. REv. 478, 487 (1973).

32. See, e.g., SENATE REPORT No. 47 , supra note 30 , at 1 ; House REPORT, supra note 30 , at 1.

33. See supra note 19.

34. HOUSE REPORT, supra note 30 , at 1.

35. Howey, 328 U.S. at 299. 


\section{United States Supreme Court Precedent}

The United States Supreme Court has never directly considered the validity of the sale of business doctrine, nor held that traditional stock-meaning stock that possesses certam customary characteristics such as the payment of dividends-is not a security. The courts that have endorsed the sale of business doctrine nonetheless use Supreme Court precedent to support their departure from the statutory definition. $^{36}$ This Comment argues that the Suprenie Court cases are ambiguous, and are imsufficient to overcome the presumption that stock is within the terms of the statute.

\section{The Howey Test}

The defendants in SEC v. W.J. Howey Co. ${ }^{37}$ sold contracts for agricultural land and for cultivation, harvesting, and marketimg services. The parcels of land were situated so as to inake the purchase of the service contracts a practical necessity. ${ }^{38}$ In order to determine whether the defendants' activity was covered by the Securities Acts, the Court looked to the underlying transaction to determine whether it was an offermg of an investment contract and thus within the Acts' catchall definition sections.

The Court held that under the securities laws, an investment contract is a transaction in which a person (1) invests money (2) in a common enterprise, and (3) is led to expect profits solely from the efforts of a promoter or third party. ${ }^{39}$ The contracts in Howey, the Court found, possessed all three of these elements. ${ }^{40}$ Thus, while the Howey Court disregarded form for substance, it did so in order to augment the Acts' coverage. $^{41}$

In the sale of business context, the critical decision is whether to apply the three elements of the Howey test. The sale of $100 \%$ of a business' stock satisfies neither the first nor third element of Howey. Thus, once the Howey test is apphed, the sale of busmess stock will fail to qualify as a security. The sale of business cases hold that the Suprenie Court's decision in United Housing Foundation, Inc. v. Forman ${ }^{42}$ extended Howey's application from catchall instruments such as investment contracts to specifically listed instruments such as stock. ${ }^{43}$

\footnotetext{
36. See, e.g., Sutter, 687 F.2d at 200; King, 673 F.2d at 345; Frederiksen, 637 F.2d at 1151 .

37. 328 U.S. 293 (1946).

38. Id at $295-96$.

39. Id. at $298-99$.

40. Id at 299-300.

41. Id. at $298-99$.

42. 421 U.S. 837 (1975).

43. King, 673 F.2d at 344; Canfield v. Rapp \& Son, Inc., 654 F.2d 459, 463-64 (7th Cir. 1981).
} 


\section{Supreme Court Extensions of Howey}

a. United Housing Foundation, Inc. v. Forman

Forman ${ }^{44}$ applied the Howey test to an instrument claimed to be stock, but lacking the traditional attributes of that instrument. In Forman, purchasers of apartments in a low-income housing project were required to buy "stock" in the nonprofit company that owned and operated the project. The stock did not possess the characteristics traditionally associated with stock: it did not carry the right to receive dividends; it was not negotiable; it conferred no voting rights; and it would not appreciate in value. ${ }^{45}$

The Supreme Court held that the stock was not a security. First, the Court held that the name assigned the instrument was not dispositive. The Court justified this conclusion by discussing the importance of an inquiry into the economic reality of the transaction. ${ }^{46}$ It acknowledged that the name of the instruinent could be helpful in determining whether it was a security-as, for example, where the instrument reflected some of the significant characteristics of stock. The instruinent in Forman, however, did not possess any of these traditional characteristics. ${ }^{47}$

The Court then considered the application of the Howey investment contract test. Respondents argued that what they agreed to purchase was "commonly known as a 'security," rather than an investment contract, in spite of the fact that both types of instruments are in the catchall definition section. In response to this argument the Court observed, "We perceive no distinction, for present purposes, between an 'investment contract' and an 'instrument commonly known as a "security." "48 In either case, the Court lield, the basic test for determining the existence of a security is the Howey test. ${ }^{49}$ The Court then applied that test and lield that the stock was not a security as it was not purchased for profit. $^{\text {so }}$

The Court's opimion, however, is unclear as to whether the Howey test is required in all situations. The circuit courts are divided on this issue. Some circuits have read Forman as requiring an assessment of economic reality even if the stock possesses traditional attributes. These courts use Forman to justify the application of the sale of busi-

44. 421 U.S. 837 (1975).

45. Id. at 851 .

46. Id. at 848-51.

47. Id. at 851 .

48. Id. at 852 .

49. Id.

50. Id. 
ness doctrine. ${ }^{51}$ Other circuit courts have held that a transaction's substance is to be examined only if the stock lacks traditional attributes. These courts have rejected the sale of business doctrine. ${ }^{52}$

\section{b. Marine Bank v. Weaver}

Marine Bank v. Weaver, ${ }^{53}$ the latest Supreme Court case in this area, held that a bank certificate of deposit was not a security. The Court found protection of the securities laws unnecessary because the mstrument was already subject to federal banking regulations. The Court's precise use of the banking regulations was unclear, however. The Court may have cited the regulations to distinguish the certificate of deposit from other instruments specifically listed in the statute, and for that reason to find that the imstrument was not a specifically listed security. But the decision also could be viewed as permitting a specifically listed instrument to avoid the statute's literal terins because the regulatory structure of the banking industry provided a "context that otherwise require[d]" exclusion of the instruinent. ${ }^{54}$ If Marine Bank's results can be viewed as indicative of a desire on the part of the Court to constrict the scope of the securities laws, its approach is consistent with the philosophy underlying the sale of business doctrine.

\section{The Sale of Business Cases}

\section{Development of the Doctrine}

The sale of business doctrine emerged in 1979 in a series of federal court decisions. These decisions, however, contained little analysis of the doctrine. Chandler v. Kew, Inc. ${ }^{55}$ the first case to apply the doctrine, noted that Forman required an inquiry into the economic reality of a transaction. However, it simply concluded that the sale of an incorporated business differed from the sale of stock, and thus did not constitute the sale of securities. Subsequent cases interjected the Howey test as the deteruninant of economic reality. ${ }^{56}$

The first analytical discussion of the doctrine was the Seventh Circuit's decision in Frederiksen v. Poloway. ${ }^{57}$ Frederiksen purchased the assets and stock of NSM from Poloway, NSM's sole shareholder. The sales agreement provided that Frederiksen would employ Poloway on a

51. Canfield, 654 F.2d at 463-64; Frederiksen, 637 F.2d at $1150-51$.

52. Coffin, 596 F.2d at 1204.

53. 455 U.S. 551 (1982).

54. See infra text accompanying notes 77-82.

55. [1979 Transfer Binder] FED. SEC. L. REP. (CCH) \ 96,966 (10th Cir. 1977).

56. E.g., Bula v. Mansfield, [1979 Transfer Binder] FED. SEC. L. REP. (CCH) I 96,964 (D. Colo. 1977).

57. 637 F.2d 1147 (7th Cir.), cert. denied, 451 U.S. 1017 (1981). 
commission basis to assist him in running the business. In response to a breach of contract suit by Poloway, Frederiksen sued Poloway for securities fraud. ${ }^{58}$

The court held that the sale of business doctrine apphed and dismissed Frederiksen's suit. The court justified application of the doctrine on legislative intent and statutory interpretation grounds. The court stated that the legislative intent of the securities laws indicated that their scope should be limited to transactions entered into for investment as opposed to commercial purposes. Commercial purposes were held to be those motivated by a desire to use, consume, occupy, or develop. $^{59}$ Since the buyers assumed manageinent of the business, their purposes were leld to be commercial. The court concluded that they were not the type of plaintiffs that Congress intended to protect under the securities laws. ${ }^{60}$

The court also argued that the statutory definition of a security need not be applied literally. It based this conclusion on three factors. First, the definitions in both Acts are preceded and qualified by the context clause. Second, it is a principle of statutory construction that "a thing inay be within the letter of the statute and yet not within the statute, because not within . . . the intention of its makers."61 Third, Forman and its progeny rejected a literalist approacls to the definition of a security, and advocated analysis based on economic reahties. ${ }^{62}$ The court then applied the Howey/Forman economic reality test and concluded that the sale of the business was not within the scope of the statute because there was no expectation of profits froin the efforts of others. $^{63}$

At the sane time, courts in other circuits rejected the doctrine, interpreting Forman to require the application of the Howey test only if the instrument lacked the traditional attributes of stock. ${ }^{64}$ Because these cases always found these attributes to be present, they never reached the second step of the Forman test.

\section{Recent Cases}

The disagreenent ainong the federal courts over the sale of business doctrine has becoine inore pointed in recent months. The Second

58. Id. at 1149 .

59. Id. at 1150 (quoting Forman, 421 U.S. at 852-53).

60. Id at 1150-52.

61. Id. at 1150 (quoting Church of the Holy Trinity v. United States, 143 U.S. 457,459 (1892)).

62. Id. at $1150-51$

63. Id.

64. See, e.g., Coffin, 596 F.2d at 1204. 
Circuit rejected the doctrine in Golden v. Garafalo. ${ }^{65}$ In Sutter v. Groen, ${ }^{66}$ the Seventh Circuit reconsidered the issue in light of Golden and Marine Bank and reaffirmed its earlier acceptance of the doctrine.

\section{a. Golden v. Garafalo}

Golden involved allegations of fraud in the sale of $100 \%$ of a ticket brokerage's stock from a sole shareholder to the plaintiffs. Plaintiffs intended to manage the business directly. The court assumed that the transaction was structured as a transfer of shares rather than assets in order to maintaim an advantageous lease structure. ${ }^{67}$ The court recognized that these facts presented a paradigmatic context for application of the sale of business doctrine, if its validity were accepted. ${ }^{68}$ Nevertheless, the court rejected the doctrine. In reaching its decision the court noted that the Supreine Court's decisions lent support to the view that conventional stock is a security whether or not the underlying transaction involves a sale of business. The cases treated the determination of whether a particular transaction was a "security" as one that did not vary with the relative holdings of the parties or their intentions in a particular transaction. For exainple, it was only changes in the instruments themselves, rather than how much was sold, that would convert the shares in Forman into "stock." In contrast, the sale of business doctrine treats a given instrument as a security for some purposes but not for others. ${ }^{69}$ The court also found indirect support in the fact that, with the exception of the certificate of deposit in Marine Bank, the Supreme Court cases all dealt with nonconventional forms of securities. $^{70}$

After considering the Supreme Court precedent, the court analyzed the language of the definition. It stated that there was little reason for the drafters to use words such as "stock" and "treasury stock" unless their intention was to include all such instruments as commonly defined. ${ }^{71}$ The specific terms of the definition were followed by catchall phrases such as "investment contract" to encompass instruments not covered by the specific terms. If the "econounic reality" test were to be the test of the definition, only the general catchall terms would have

65. 678 F.2d 1139 (2d Cir. 1982).

66. 687 F.2d 197 (7th Cir. 1982).

67. The court assumed that the lease was decisive in determining that the transfer would be through a sale of shares rather than assets. 678 F.2d at 1140 .

68. The District Court for the Southern District of New York had applied the sale of business doctrine and dismissed the complaint. 521 F. Supp. 350 (S.D.N.Y. 1981), rev'd, 678 F.2d 1139 (2d Cir. 1982).

69. 678 F.2d at $1143-44$.

70. Id. at 1144 .

71. Id. 
been necessary. ${ }^{72}$ The court then noted that there was no legislative history contradicting its reading of the statutory language and that, moreover, "This understanding of Congressional intent . . . has been almost universally accepted by the courts, the relevant agency and the bar for over 40 years." 73

Another reason for rejecting the doctrine was the administrative probleins that it would engender. The doctrine would allow the application of the Acts to turn on uncertain and slippery factors that would vary in each case. ${ }^{74}$ Adoption of the sale of business doctrine would involve determining the existence of an intent to nianage. Cases involving the purchase of less than $100 \%$ of the stock would also present a problein. ${ }^{75}$ In the end, the sale of business doctrine would turn upon the distinction between commercial and investnient transactions, a distinction of dubious value in the context of corporate stock. ${ }^{76}$

\section{b. Sutter v. Groen}

The Seventh Circuit reaffirmed the sale of business doctrine in Sutter v. Groen. ${ }^{77}$ Sutter involved the sale of $100 \%$ of Bret Broadcasting's stock to Happy Radio, a corporation that planned to nianage the business. Plaintiff Sutter purchased 70\% of the stock of Happy Radio. The court held that an acquisition of inore than 50\% of a coinpany's stock created a presumption of entrepreneurship, and that unless Sutter could rebut this presumption, the transaction would not be subject to the securities laws. ${ }^{78}$

Because the court realized that Forman dealt with unconventional stock, and thus did not directly support its position, it relied primarily on the Suprenie Court's decision in Marine Bank. However, Sutter offered a more coinplex analysis of the approach taken by Marine Bank. The Marine Bank Court had lield that the certificate was not covered by the securities laws because it was adequately covered by the banking laws. The Sutter court also noted, however, that the certificate of deposit in Marine Bank was a type of note, and that a note is one of the instruinents specifically listed in the statutory definition of a security. ${ }^{79}$ Thus Sutter argued that the Court in Marine Bank departed from the literal terins of the statute with respect to one of the specifically listed imstruments. Therefore, it held that Marine Bank provides support for

72. Id.

73. Id. at $1144-45$.

74. Id. at 1145 .

75. Id. at 1146 .

76. Id.

77. 687 F.2d 197 (7th Cir. 1982).

78. Id. at 202-04.

79. Id. at 200 . 
a similar approach with respect to "stock."

After thus holding that Marine Bank sanctioned a departure from the hiteral terms of the statute in appropriate situations, Sutter held that Congress intended that such a departure occur in the sale of business context. The court concluded that Congress' primary concern was with investor protection and that it did not intend the sale of a business to be covered by the securities laws. ${ }^{81}$

Finally, the court addressed the administrative problems einphasized by Golden. While Happy Radio's purchase of $100 \%$ of Bret Broadcasting's stock would clcarly fall within the sale of business doctrime, Sutter's purchase of Happy Radio stock was less clearly covered, since he was only a $70 \%$ owner after the transaction. The court adopted a presuinption that a purchaser who acquires inore than $50 \%$ of the corporation is an entrepreneur rather than an investor. The presuinption could be rebutted by showing that the purchaser's inain purpose was investinent. ${ }^{82}$ The court remanded the case to allow Sutter the opportunity to rebut the presumption.

\section{II}

\section{ANALYSIS}

This Comment argues that the sale of business cases should be rejected for three reasons. First, the Securities Acts specifically define a security to include "stock." Second, the sale of business cases provide inadequate reasons for departing from the definitions' specific terms. Third, the application of the doctrime would engender considerable administrative difficulties.

\section{A. Inclusion of "Stock" in the Statutory Definition}

Courts should not depart froin an express statutory inandate without a coinpelling reason for doing so. By specifically including stock in the statutes that define securities, ${ }^{83}$ Congress has provided clear and

80. Id. at 200-01.

81. The court gave three reasons for this conclusion. First, im a message to Congress recommending the enactment of legislation, President Roosevelt called for the regulation of exchanges in order to protect investors and reduce the opportunity for unwise speculation. SENATE REPORT No. 792, supra note 30, at 2. Second, the Report of the Senate Committee on Banking and Currency described the objective of the legislation as the prevention of the excessive use of credit for speculation, the unfair practices employed im speculation, and the secrecy surrounding the financial condition of corporations which invite the public to purchase their securities. Id. at 5 . Finally, prior to the legislation an influential book by Adolf Berle and Gardiner Means lad drawn a distinction between passive stock ownership and active inanagerial control. A. BERLE \& G. Means, The Modern Corporation and Private Property (1932). This book was part of the intellectual patrimony of the Securities Exchange Act.

82. 687 F.2d at 203.

83. See supra note 19. 
consistent direction to the courts. Moreover, while courts have interpreted more general catchall phrases, such as investment contract, ${ }^{84}$ this interpretation is not necessary for specific instruments, such as stock, which possess generally understood meamings. Finally, prior to the sale of business cases, the coverage of traditional stock by the securities laws had never been challenged by the courts and the Securities and Exchange Commission. ${ }^{85}$ In view of these considerations, the sale of business cases have inadequately justified their dismissal of the statutory definition arguinent.

Moreover, while the context clause nay sometimes allow avoidance of the Acts' specific provisions, the language of the clause states that the context must require the instrument's removal from statutory coverage. If an instrument is specifically mcluded in the definitional section of a statute, a party who desires to remove the instrument from the protection of the securities laws must affirmatively establish the existence of a context that requires removal. ${ }^{86}$ The next Section considers the justifications offered by the sale of business cases, and argues that they are inadcquate to overcome the context clause's presumption of inclusion.

\section{B. Rationale of the Sale of Business Cases}

\section{Protection of Investors}

Many of the sale of business cases, including Sutter, hold that the purpose of the Securities Acts is to protect "investors," not "entrepreneurs" who purchase $100 \%$ of a company's stock. ${ }^{87}$ They argue that such legislative intent, in the sale of busmess context, requires the exclusion of stock from the definition of a security.

84. See supra note 21 and accompanying text.

85. See Golden, 678 F.2d at 1144,45 .

Prior to 1970 , it seems to have been customary to assume that the sale of an existing incorporated business eutity through a transfer of stock would fall within the purview of the federal securities laws. In Matheson v. Armbrust, 284 F.2d 670 (9th Cir. 1960), cert. denied, 365 U.S. 870 (1961), defendant argued that $\S 10(\mathrm{~b})$ was not applicable with regard to "face to face" negotiations in an isolated transaction for the sale of the eutire capital stock of a corporation. The court responded that $\S 10(\mathrm{~b})$ and rule $10 \mathrm{~b}-5$ could be exteuded to cover transactions outside the established markets. There was no allegation that stock was not a security. Id. at 674 .

Other pre-Forman cases addressed the issue more directly. See Occidental Life Ins. Co. v. Pat Ryan \& Assocs., 496 F.2d 1255, 1261-63 (4th Cir.) (sale of $100 \%$ of the stock mvolves securities), cert. denied, 419 U.S. 1023 (1974); Bailey v. Meister Brau, Inc., 320 F. Supp. 539, 543-44 (N.D. Ill. 1970) (sale of almost all corporate stock involves securities), affd, 535 F.2d 982 (1976).

86. Exchange Nat'l Bank, 544 F.2d at 1138. As Judge Friendly observed:

So long as the statutes remain as they have been for over forty years, courts had better not depart from their words without strong support for the conviction that, under the authority vested in thein by the "context" clause, they are doing what Congrcss wanted when they refuse to do what it said.

544 F.2d at 1138.

87. See supra text accoinpanying notes $28-32$. 
This reliance on legislative intent, however, is misplaced for two reasons. First, the legislative history on this issue is inconclusive. Second, the protections which the Acts were designed to provide are similarly needed by the purchaser of $100 \%$ of a busmess' stock.

Because the legislative history surrounding the Acts is largely inconclusive, it does not support the exclusion of business purchasers from protection. While the Acts' primary emphasis may have been the protection of investors in the public exchange markets, ${ }^{88}$ the coverage of the Acts extends specifically beyond the public markets and the exchanges. For example, the antifraud provisions do not depend on an offering's public nature. Many securities, including closely held, privately offered securities, while exempt from the Act's filing requirements, ${ }^{89}$ are not exempted from the antifraud provisions of the 1933 Act, or the disclosure requirements of the 1934 Act. ${ }^{90}$

Congress imtended that the Acts result im both the full disclosure of material information and the elimination of fraudulent practices. ${ }^{91}$ While the purchaser of $100 \%$ of a corporation's stock may be in a position to demand material information and hence not need the protection of provisions that require the affinnative reporting of financial information about the corporation, he is still in need of protection against securities fraud. His need for protection is greater than that of the purchaser who only acquires the assets of a corporation, since he is purchasing the disclosed and undisclosed liabilities in addition to the assets of the business. ${ }^{92}$ In addition, where an investor purchases a controlling block but less than 100\% of the stock, the existence of even one minority share saddles the inanagement of the business witl a range of fiduciary duties. Such a purchaser is not in the same position as a purchaser of assets; his ability to correct the situation in which he finds himself is constricted by his fiduciary obligations to minority

88. See supra text accompanying notes $28-32$.

89. Sections 3 and 4 of the Securities Act of 1933 list securities and transactions that are exempt from the registration requirements of that Act. 15 U.S.C. $\$ \S 77 \mathrm{c}-77 \mathrm{~d}$ (1976). Subsections (1) and (2) of section 4 may be available to exempt privately offered stock. Id. $\$ 77 \mathrm{~d}(1)$, (2).

90. Section $10($ b) of the Securities Act of 1933 is applicable to the "purchase or sale of any security registered on a national exchange or any security not so registered." 15 U.S.C. § 78j(b) (1976) (emphasis added).

91. See supra note 32 .

92. It is also possible that unassumed liabilities may be imposed on the purchaser of all the assets of a business in some situations. For example, if the purchaser of the inventory of a manufacturing or retail entcrprise fails to give adequate notice to the creditors of the seller, he may be responsible for the seller's debts. See U.C.C. art. 6 (1978).

A purchaser of assets may also be subject to the liabilities of the selling business if the buyer uses its own stock to acquire the assets. Some courts have imposed liabilities in that case on the basis of a de facto inerger theory. See, e.g., Knapp v. North Am. Rockwell Corp., 506 F.2d 361 (3d Cir. 1974), cert. denied, 421 U.S. 965 (1975). 
stockholders. ${ }^{93}$ Thus, when a business is sold, past management inadequacies influence the current operations of the business to a greater extent than if only the assets are sold, and indicate a greater need for the antifraud provisions.

Finally, judicial construction indicates that the Acts are to be given an expansive interpretation..$^{94}$ This suggests that where there is a question as to the coverage of a specifically listed instrument, doubt should be resolved in favor of inclusion.

Thus, the sale of business cases' analyses of legislative intent is defective. The analysis lacks sufficient force to overcome the presumption that the plain meaning of the statute should control.

\section{Supreme Court Support for the Sale of Business Doctrine}

The sale of business cases argue that the Supreme Court's decisions in Forman and Marine Bank provide authority for a departure from the plam language of the definition. ${ }^{95}$ This Comment contends, however, that the ambiguity of Forman and the particular factual setting of Marine Bank coinpel the conclusion that tliese cases do not provide an adequate justification for a departure from the definition's literal terms.

\section{a. Forman}

Those cases that have upheld the sale of business doctrine cite Forman to support a requirement that the Howey test be applied in all cases to determine whether a security is involved. ${ }^{96}$ As discussed earlier, the sale of all the stock of a business would always fail this test, thus removing the transaction from the scope of the securities laws. ${ }^{97}$

This interpretation, however, is based only on dicta in the Forman case. While the Court applied the Howey test to an instrument denominated "stock," it in fact was confronting a unique instrument rather than traditional stock. Thus, it first determined that the "shares" did not possess the traditional attributes of stock. Only then did it apply the Howey investinent contract analysis. This may indicate that the Court wished to restrict Howey either to catchall instruments or to specific instruments that do not first pass the traditional attributes analysis, contrary to the meaning ascribed to Forman by the sale of business cases.

While Forman did not actually hold that the Howey test is always

93. See, e.g., Guth v. Loft, Inc., 23 Del. Ch. 255, 266, 5 A.2d 503, 510 (Sup. Ct. 1939).

94. See, e.g., Howey; Tcherepnin v. Knight, 339 U.S. 332 (1976).

95. See, e.g., Sutter, 687 F.2d at 200; Frederiksen, 637 F.2d at 1150-51.

96. See supra note 51 .

97. See supra text accompanying notes 41-43. 
required, the sale of business cases argue that its language provides persuasive authority for that proposition. ${ }^{98}$ For example, they note that the Forman Court expressly rejected the view that the name of the instrument was dispositive of its status, in favor of a substance over form approach that emphasized economic realities. ${ }^{99}$ Additionally, they note that the Court stated that the Howey test had been the touchstone of the Court's decisions interpreting the definition of a security. ${ }^{100}$ However, this analysis ignores two important factors.

$i$. Traditional attributes. First, the Forman opmion initially applied a traditional attributes analysis. The Court recognized that the name given to an instrument cannot be disregarded and may, in fact, be highly relevant, especially if the instrument possesses some of the intrinsic features customarily associated with the nanied instrunient. ${ }^{101}$ The Forman Court applied the Howey test only after applying a traditional attributes test.

A few sale of business cases acknowledge the possible relevance of the Forman traditional attributes test, but they limit its apphication to situations where there is in fact reliance on the status of the instrument as a security. ${ }^{102}$ However, while Forman speaks of the relevance of traditional attributes in the context of creating reliance, it does not indicate whether reliance is autoinatically to be presuined from the existence of the traditional attributes, or whether it must be specifically proved.

As a matter of policy, proof of actual reliance should not be required. A specific mvestor's reliance may be hard to establish. Drawing inferences from the participants' conduct may result in ritualistic maneuvering before serious negotiations, and in offers to purchase less than $100 \%$ of the stock, in an effort to preserve the protections of the securities laws. Given the difficulties of proof, the better approach is to recognize a broader forin of reliance - that of the public in general on the application of the securities laws to instruments that are clearly considered securities for other purposes.

ii. Economic reality. Second, the terin "economic reality" need not be given the broad treatinent that the sale of busmess cases have attached to it. Most of the language from Forman cited as supporting the Howey test's application to stock refers to the application of an undefined "economic realities" test rather than to the Howey test im par-

98. See, e.g., Frederiksen, 637 F.2d at $1150-5 \mathrm{I}$; King, 673 F.2d at 345.

99. Frederiksen, $637 \mathrm{~F} .2 \mathrm{~d}$ at $1150-51$.

100. King, 673 F.2d at 344.

101. 421 U.S. at 850-51.

102. See, e.g., Golden v. Garafalo, 521 F. Supp. 350, 357 (S.D.N.Y. 1981), rev'd, 678 F.2d 1139 (2d Cir. 1982). 
ticular. ${ }^{103}$ Even assuming that Forman requires the application of some type of economic realities test in order to accommodate misnamed instruments such as the "shares" in Forman, the Howey test is neither required nor appropriate. Instead, an economic realities analysis could be satisfied by a traditional attributes test that is narrower than the Howey test.

An inquiry into economic reality that is consistent with Forman might be met by an analysis of the nature of the instrument rather than of the transaction. In Forman, the Court looked beyond the name and considered whether the instrument involved possessed the traditional attributes of stock. ${ }^{104}$ The case can thus be regarded as an analysis of the economic reality of the shares based on whether they paid dividends, were transferable, had voting rights, or possessed other attributes of stock.

In addition, Forman's statement that there was no distinction between an "investment contract" and an "instrument commonly known as a 'security" $" 105$ is cited by some of the sale of business cases to support the application of the Howey test to the specific instruments as well as to the catchall terms such as "investment contract." 106 However, because the phrase "instrument commonly known as a "security" "is itself a catchall rather than a specific phrase, the application of Howey is not justified.

Thus, Forman does not necessarily require the application of the Howey test to transactions involving traditional stock. The ambiguity surrounding the proper interpretation of Forman argues against using it to justify the sale of business doctrine's avoidance of the clear terms of the definition.

\section{b. Marine Bank}

The Sutter court's reliance on Marine Bank is also misplaced. While the Marine Bank Court may have denied security status to one of the specifically listed instruments, the analysis that it applied is distinguishable from that required by the sale of business doctrine.

The Court held that a certificate of deposit was distinguishable from other long-term debt obligations because purchasers of the certificates of deposit were adequately protected by the federal banking regulations. ${ }^{107}$ This analysis, however, is a static one that focuses on the imstrument itself and the protections and regulations that accompany it.

\footnotetext{
103. 421 U.S. at $848-49$.

104. Id. at $848-51$.

105. Id. at 852 .

106. See, e.g., King, 673 F.2d at 344-45.

107. 455 U.S. at 558-59.
} 
The analysis employed by Marine Bank did not look to the varying circumstances of each transaction, as would be required by the sale of business doctrine.

Moreover, even to the extent Marine Bank sanctioned the exclusion of specifically listed instruments in an appropriate context, the context involved was distinguishable from that of the sale of all of a busmess' stock. No statutory regime coinparable to that found in the banking industry has preeinpted the area of stock sales. Thus the burden remains on the proponents of the sale of business doctrine to establish an appropriate context that would require departure from the hiteral terins of the statute. No such context has been deinonstrated by the sale of business cases.

In addition, Howey is not cited in the Marine Bank opimion. It is possible that the application of Howey would not have inade a difference in Marine Bank, because the Marine Bank facts would have satisfied the test's requireinents. However, the Court's failure even to inention Howey may indicate that the Court is skeptical about Howey's utility as a pervasive test of security status, and suggests that its application is not required in the sale of business context.

\section{Administrability}

Application of the sale of business doctrine generates considerable administrative probleins. While the difficulties are not insuperable, they indicate that exclusion of stock from statutory coverage is undesirable.

First, inost of the sale of business cases, whether focusing on the inodified Howey test or a commercial/investment dichotoiny, einphasize the purchaser's control over the business. ${ }^{108}$ Thus, even if the purchase of $100 \%$ of a business' stock is clearly encoinpassed within the doctrine, it is unclear whether the doctrine would be extended to the purchase of a controlling block of less than 100\%. However, the underlying rationale of the sale of business doctrine seens to require its extension to encoinpass such situations. While the first eleinentinvestment in a common venture-would be inet, the "efforts of others" requirement would reinain unsatisfied. The purchaser's profits are not to be derived froin the entrepreneurial or inanagerial efforts of others. The power to change inanagers or assume direct control would be present, as would the power to "suggest" managerial decisions.

The application of the doctrine to less than $100 \%$ of the stock inay present a factually difficult question as to when a purchaser inay be deeined to possess control. In each case where a violation of the securi-

108. See, e.g., Frederiksen, 637 F.2d at 1150. 
ties laws is alleged, an extensive factual inquiry into the workings of the issuing company would be necessary. In Bronstein v. Bronstein, ${ }^{109}$ the court specifically rejccted the notion that a court should "delve into the workings of a vahidly existing business corporation and the relationship of the shareholders, just to make the threshold determination of jurisdiction." The court in Golden also stressed these administrative diffculties. It noted that 'In 'economic reality,' considerably less than $100 \%$, and often less than $50 \%$, of outstanding shares may be a controlling block . . . . The dangers in creating uncertainty as to the scope of the Acts and in generating shppery legal and factual issues going to jurisdiction are substantial." 110 The court held that Congress did not want the courts to get involved in such issues. ${ }^{111}$

Sutter's presumption of entrepreneurship where a purchaser holds more than 50\% of the common stock of a corporation atteinpts to respond to these administrative concerns. The presumption, however, does not adequately deal with the problem. In the first place, it is likely that there will be problems of attribution of family members' holdings, proxy control, voting trusts, and other agreements whose legal impact inust be established before it can be determined whether a party's holdings exceed 50\%. In addition, control as to one area of corporate activity may not constitute control as to another area. Majority shareholders certainly do not control all corporate action. Major corporate activities, including mergers and decisions to sell all of the assets, often require greater than majority vote. ${ }^{112}$ In addition, as discussed earker, the options of the purchaser are circumscribed by judicial obligations to mimority stockholders. Thus, the 50\% presumption is madequate for determining entrepreneurship.

Finally, aside from creating administrative difficulties in ascertaining control, the application of the doctrine may lead to anomalous results. For example, an imstrument may be a security in one transaction, but not in another. The purchaser of $45 \%$ of a business' stock may be held to have purchased a security, while a purchaser of 55\% imight not. Moreover, the same instrument in a single transaction may be a security as to one party but not as to another. For example, A nay purchase $100 \%$ of a business' stock from B and C, who hold $70 \%$ and $30 \%$ respectively. C would clearly meet the Howey investor test and would be deemed to have sold a security if he were a plaintiff or counterclaimant.

109. 407 F. Supp. 925,929 (E.D. Pa. 1976).

110. Golden, 678 F.2d at 1146.

111. Id.

112. See, e.g., CAL. CORP. CODE $\S 1111$ (West 1977) (where a disappearing corporation in a merger is a close corporation, a two-thirds vote of each class of the outstanding shares is required unless otherwise provided in articles). The corporation's articles of incorporation may also require a superınajority vote for certain transactions. 
If $A$ sued $C$, however, the stock which $C$ sold would not be securities as to $A$. Moreover, whether $B$ will be deemed to have sold securities and be protected by the federal securities provisions depends on the scope given to the sale of business doctrine.

While such anomalous results are not necessarily unacceptable, they are a departure from the Supreme Court cases upon which the doctrine depends. In neither of the situations confronted in Forman or Marine Bank could the Court's analysis have led to these inconsistencies. In Forman, only changes in the instruments themselves could have converted the shares into securities. In Marine Bank, once the bank certificate of deposit was deemed not to be a security, its status would remain constant and would not vary as a function of degrees of control. Thus, the anomalous results reached in the hypothetical situations described above could not have arisen.

\section{CONCLUSION}

The recent einergence of the sale of business doctrine threatens to constrict substantially the protections of the federal securities laws. If accepted, the doctrine would exclude froin the Acts' coverage the sale of $100 \%$ - or even a controlling block-of a business' stock. The federal courts have reached inconsistent positions on the validity of the doctrine, and the resolution of the controversy is of pressing importance to purchasers and sellers of businesses.

This Comment has argued that the sale of business doctrine represents an unjustifiable departure from the specific terms of the statutory definition. Moreover, its application would create considerable administrative difficulties and inight lead to anomalous and capricious results. Given the significant impact of the doctrine and the directly confiicting approaches which the appellate courts have applied, it is possible that the Supreme Court may soon address the issue. This Comment argues that those courts that have declined to apply the doctrine present the better reasoned view, and that the sale of business doctrine should be rejected.

Jacque Lynn Nims*

* A.B. 1980, Stanford University; third-year student, Boalt Hall School of Law, University of California, Berkeley. 